\title{
The champions of drug development
}

\author{
Our new podcast series 'Hope Lies in Dreams' highlights the importance of visionaries in shepherding drugs \\ through the setbacks of drug development to commercial success.
}

$\mathrm{D}$ rug development is a long game. And when it comes to shepherding an entirely new therapeutic

modality to market, it is a very long game indeed. Our current podcast series, Hope Lies in Dreams, focuses on the history of one such therapeutic modality: antisense oligonucleotides (ASOs). It highlights the many highs and lows that drug makers experience bringing a completely new type of drug molecule to market. But most of all, it showcases the importance of an individual personality - and the team around them-in pushing a drug program to commercial success, despite clinical disappointments, investor flight, big pharma skepticism and market failures.

As recounted in our podcast, Ionis had to persevere for decades before attaining commercial success with the ASO Spinraza in spinal muscular atrophy. History shows us this is not unique. New therapeutic modalities-the first recombinant proteins, monoclonal antibodies (mAbs), gene therapies and oligonucleotide therapiesoften follow a twisted path to market. They routinely break the backs of the startups founded around them, empty the pockets of investors, and may even end up gathering dust on pharmaceutical company shelves before they ultimately bear fruit.

In the case of replacement proteins, Genentech was the startup that nucleated recombinant DNA technology. Founded in 1976 with venture capital money, it supplied the know-how that created the first recombinant DNA product (Humulin, a recombinant insulin marketed in 1982 by Eli Lilly) and the first commercial drug from a biotech company (Protropin, a recombinant human growth hormone first marketed in 1985). Genentech created an entirely new way of developing drugs. But it went after the lowest-hanging fruit: recombinant protein alternatives to already approved plasma-purified products. Other new therapeutic modalities proved harder to crack. mAbs, ASOs, small interfering RNAs (siRNAs), gene therapies and gene-editing products have presented drug makers with an added challenge: how to develop and deliver a type of therapeutic molecule that the human body has never encountered. Little wonder that the timelines for maturation and marketing of such drugs are many years longer than the 10-12+ years needed for a typical small-molecule drug. And no surprise that bankrolling the development of such therapeutic modalities can take hundreds of millions, if not billions, of dollars.

Take Centocor, a company founded in 1979. It took nearly 20 years before turning hybridoma technology into market success with the mAb Remicade (infliximab). Along the way, the company faced financial ruin with the failure of its anti-septic shock $\mathrm{mAb}$ Centoxin (nebacumab); indeed, for nearly the entirety of its history, Centocor lost money: \$194 million in 1992, \$74 million the next year, \$127 million year the year after that. On and on it went, until the company finally got ReoPro (abciximab) on the market in 1994 and Remicade four years later.

Since Ionis was founded in 1989 , the company has eaten through $\sim \$ 1.5$ billion of investor money to fuel its voracious R\&D engine. Its first commercialized product, Vitravene (fomivirsen, 1998), was withdrawn; its second approved product, Kynamro (mipomersen, 2013), was a commercial failure. And yet somehow the company still found a way to survive and mature antisense into an established drug modality, curing a disease that had confounded medicine.

What is striking about the ASO storyand of nearly every other successful therapeutic modality-is the importance of a single personality in overcoming the disappointments and setbacks of drug development and finally attaining commercial success. In the case of Ionis, that individual was former CEO Stan Crooke.

For Crooke, the needs of shareholders, although important, always fell somewhere below the needs of patients and the needs of the science. Ionis's programs faced a bewildering number of obstacles and setbacks over the three decades it took to get to Spinraza. And yet, as CEO, Crooke always somehow found a way through: raising funds when company valuations were low and, in the dark years, surviving on loans, special financing vehicles and debtanything that kept the science moving and the drugs progressing through the pipeline.
Look at any other successful biotech company developing groundbreaking drugs and one can find similar individuals: Michael Wall, Centocor's founder, who kept the company afloat despite investor lawsuits and development flops, allowing it to finally emerge to launch Remicade; Alnylam's John Maraganore, who oversaw development of the first siRNA drug, Onpattro (patisaran), despite clinical disappointments and investor and pharma skepticism; Julian Adams, who kept Velcade (bortezomib) alive at Millennium when executives wanted to kill the drug; Brian Druker, who battled to convince Novartis executives not to shelve Gleevec (imatinib), the drug that launched precision medicine; Vicki Sato, who oversaw the development of Vertex's key antiviral drugs Agenerase (amprenavir), Lexiva (fosamprenavir) and Incivek (telaprevir) when pharma was abandoning infectious disease; BioNTech's Katalin Karikó and Uğur Şahin, who persevered with mRNA vaccines when many dismissed the approach; and Andrea van Elsas (now at Third Rock Ventures), who championed Keytruda (pembrolizumab) when Schering-Plough executives wanted to shelve Organon's checkpoint inhibitor.

These are leaders who believe in their drugs and the teams developing them. These are the visionaries. These are the individuals who refuse to give up on their drug technologies, despite naysayers and skeptics and corporate executives myopically chasing market share.

While every drug development program is characterized by its own unique idiosyncrasies and setbacks, successful drug programs share one thing: a pioneering individual who displays the true grit needed to bring a transformative drug technology to market.

Such individuals may drive their teams too hard, exert too much control and show a persistence that sometimes borders on sheer bloody-mindedness. But they are the ones who make the difference. They are the force behind many of the drugs that change the face of medical practice. Let's salute them and celebrate them.

Published online: 23 September 2021 https://doi.org/10.1038/s41587-021-01095-z 